\title{
The Effectiveness of the Sale and Purchase Agreement for Online Business People in Bone Regency
}

\author{
Yusriadi* \\ Program Studi Ilmu Hukum, Sekolah Tinggi Ilmu Hukum Pengayoman, Indonesia \\ Diterima: Maret 2019; Disetujui: Maret 2019; Dipublish: April 2019 \\ *E-mail: yusriadi.yusriadi@uqconnect.edu.au
}

\begin{abstract}
The influence of globalization and economic growth in business activities, the existence of buying and selling rules is a new paradigm for the implementation of the law in Indonesia. In business activities, it is never separated from the problem of an agreement. Actually, buying and selling agreements can be made online that are made on the basis of mutual trust. But the fact is that if a problem occurs in the future, we cannot do much to solve is related to the problem of the agreement that has been done before. This research was conducted in Bone Regency, South Sulawesi Province. This study uses a normative approach combined with a sociological approach to see the reality in the field. The research informants consisted of 10 online traders and 10 consumers, data collection techniques used questionnaire and interview systems. Based on the results of research on the effectiveness of buying and selling agreements by online traders in Bone Regency, they are considered effective. The factors that influence the effectiveness of buying and selling agreements by online traders are knowledge, trust, and habits.
\end{abstract}

Keyword: Effectiveness, Agreements, Online Traders, Indonesia

\begin{abstract}
Abstrak
Pengaruh globalisasi dan pertumbuhan ekonomi dalam kegiatan bisnis, keberadaan aturan jual beli adalah paradigma baru untuk implementasi hukum di Indonesia. Dalam kegiatan bisnis, itu tidak pernah lepas dari masalah perjanjian. Sebenarnya, perjanjian jual beli dapat dilakukan secara online yang dibuat atas dasar saling percaya. Tetapi faktanya adalah jika masalah terjadi di masa depan, kita tidak bisa berbuat banyak untuk menyelesaikannya terkait dengan masalah perjanjian yang telah dilakukan sebelumnya. Penelitian ini dilakukan di Kabupaten Bone, Provinsi Sulawesi Selatan. Penelitian ini menggunakan pendekatan normatif yang dikombinasikan dengan pendekatan sosiologis untuk melihat kenyataan di lapangan. Informan penelitian terdiri dari 10 pedagang online dan 10 konsumen, teknik pengumpulan data menggunakan kuesioner dan sistem wawancara. Berdasarkan hasil penelitian tentang efektivitas perjanjian jual beli oleh pedagang online di Kabupaten Bone, mereka dianggap efektif. Faktor-faktor yang mempengaruhi keefektifan perjanjian jual beli oleh pedagang online adalah pengetahuan, kepercayaan, dan kebiasaan.
\end{abstract}

Kata kunci: Efektivitas, Perjanjian, Pedagang Online, Indonesia

How to Cite: Yusriadi. (2019). The Effectiveness of the Sale and Purchase Agreement for Online Business People in Bone Regency. Journal of Education, Humaniora and Social Sciences (JEHSS). 1 (3): 177-.

\section{INTRODUCTION}

Every human being will try to fulfill their daily needs, because of their limitations; humans need other people to fulfill their needs. Based on this, business activities are born, with the term buying and selling activities. Along with the influence of globalization and economic growth in online business activities, the existence of treaty law is a new paradigm in the development of law in Indonesia. By taking the basis of the rules of the applicable business law, the agreement in its development in the world of online commerce, so that requires its own interpretation for both academics and practitioners.

The law should provide justice, certainty, and expediency because that is the purpose of the law. Therefore, the law should regulate online trading; provide justice, certainty, and benefits to the parties that make buying and selling. In this connection, an agreement that occurs cannot be 
based only on the principle of freedom of sale and purchase. There needs to be a limit to the operation of the principle of freedom of sale and purchase carried out by business people. Many things and around the agreement are not regulated in law, and if there are rules, they are not always coercive, in the sense that one can override them by self-made rules.

Self-regulation by each person is stated in the agreement based on the principle of freedom. The arrangement in the agreement is as powerful as the provisions of the law (according to Article 1338 paragraph (1) of the Civil Code). Someone can arrange anything in the agreement, as long as it is not prohibited by law.

Bone Regency is very fundamental in online business activities, which is sometimes never separated from the problem of agreements between business actors. Therefore, it can be ascertained that if business people ignore aspects of the agreement in their business, then, of course, it can be detrimental to the business person, and things like this have become a daily sight in business activities.

In everyday life, especially in business activities, we are never separated from the problem of an agreement. Actually, this agreement can be done online which is made on the basis of mutual trust, it will still be true if there is a problem in the future, and we cannot do much to solve it because of the lack of evidence relating to the agreement that has been done before. For that all agreements should be written to avoid problems that will occur in the future, thus, we must have the basic knowledge of the agreement. This is an interesting one to study online business activities that take place in Bone Regency.

\section{RESEARCH METHOD}

This research was conducted in Bone Regency, South Sulawesi Province. This study uses a normative approach combined with a sociological approach to see the reality in the field. The research informants consisted of 10 online traders and 10 consumers, data collection techniques used questionnaire and interview systems. Data collection techniques used was observation, questionnaires and interviews. The data analysis method used in this study uses a percentage technique to find out how effective the agreement is, besides that it is used to study documents from certain literature to describe the effectiveness of the sale and purchase agreement for online business people in Bone Regency.

\section{RESULT AND DISCUSSION}

The results of the study are presented in a quantitative form, namely the description of business people in Bone Regency on the effectiveness of the agreement. The research data shows that there are 7 online businesses (23.33 percent) whose effectiveness on the implementation of the agreement is categorized as very effective, 14 business people (46.66 percent) are categrized as effective, 9 business people ( 30 percent) are categorized as less effective and no online business people with the effectiveness of the agreement is categorized as ineffective.

The effectiveness of the implementation of the agreement is very fundamental because the business starts from the existence of agreements between business people so that the terms of the terms of the agreement are ignored, it will cause fatal things for the businessman himself. To determine the factors that influence the effectiveness of the implementation of the agreement, there are several things that need to be considered. The results of the research in the field that the things that affect the effectiveness of the agreement are as follows:

\section{Knowledge Factor}

Knowledge is a branch of philosophy that deals with the nature and scope of knowledge, presuppositions, and fundamentals, as well as accountability for statements regarding knowledge, possessed (Bakhtiar, 2004). Knowledge with all that is known about a particular object, including knowledge (Suriasumantri, 2005). Knowledge is divided into two types: 1) Scientific knowledge is all the results of human understanding obtained using the scientific 
method; 2) Non-scientific knowledge is knowledge obtained by means that are not included in the scientific method category (Surajiyo, 2007).

The thing that most influences the effectiveness of the implementation of the agreement is the level of knowledge possessed by the business person himself, in general, in making an agreement they do not know the things that are a condition in making an agreement so that the legal aspects of the agreement are ignored. In terms of the background of business people in Bone District, the highest level of education generally only reaches High School. Although Indonesia has several comparative advantages of natural and human resources (Yusriadi, 2018a).

By mastering the criteria of business knowledge, it is all the initial capital that is owned for the success of the business. So starting a business doesn't just use your own methods and try it out. If someone already has good business experience, then knowledge of the business agreement will be better (Sulitnih, 2013).

\section{Trust Factor}

Trust is mutual trust in the community that is united with each other and contributes to increasing social capital (Fukuyama, 2001). Relevant economic components are inherent in the culture that exists in a society that will form a wealth of social capital (Francois, 2003). There are two kinds of beliefs: 1) trust in individuals we know; 2) trust in people we don't know, but will increase because of our comfort in the knowledge of social structures (Pretty \& Ward, 2001).

In addition to the knowledge factors possessed by business people, other factors that influence are trust. In general, online businesses in Bone Regency in conducting agreements are only conducted on a chat basis made on the basis of mutual trust. The result can be fatal if later problems arise. From the results of research in the field, the agreement made in chat is only devoted to the sale and purchase agreement.

One form of implementing bureaucratic reforms is in the form of bureaucratic innovations, such as e-government that have an impact on building trust between the government and its citizens fundamentally for good governance (Yusriadi, 2018b).

\section{Habit Factor}

Another thing that becomes a factor influencing the effectiveness of the implementation of the agreement, besides the knowledge factor and the trust factor, is a habit factor. In general, online businesses in Bone Regency in making agreements are very influential from the prevailing habits in the place. From the results of the research conducted, it confirms that the underlying online business in Bone Regency is only chattering because apart from the mutual trust factor it has also become a common habit in the community. Standard procedures are part of the instrument (Yusriadi, 2018c).

\section{CONCLUSION}

Understanding the agreement as contained in Article 1313 of the Civil Code states that an agreement is an act of one person or more binding itself to one person or more. An agreement is an action that occurs in accordance with the formalities of existing legal regulations depending on the suitability of the wishes of two or more people intended for the emergence of legal consequences of the interests of one party at the expense of another party or for the mutual benefit of each party (Patrik, 1988). An objective requirement because of the object of the agreement made (Subekti, 1991). The elements of the agreement can be categorized as follows: 1) "essentials", that is, the element of agreement without which consent is impossible; 2) "natural", that is, the elements of the law are determined as regulating regulations; 3) "accidentally", which is an element which the parties added to the agreement because the law does not regulate it (Setiawan, 1979).

Based on the theoretical description tested through research with data analysis methods on the effectiveness of the implementation of agreements for online business people in Bone Regency can be categorized as effective. The factors that influence our knowledge, beliefs, and habits, it is expected that online businesses have basic knowledge of agreements, to avoid 
Yusriadi. The Effectiveness of the Sale and Purchase Agreement for Online Business People in Bone

problems that arise later on. Further research is recommended related to guarantees in an agreement.

\section{REFERENCE}

Bakhtiar, A. (2004). Filsafat Ilmu. Yogyakarta: Ar ruzz Media.

Francois, P. (2003). Sosial Capital and Economic Development. Routledge. Fukuyama, F. (2001). Sosial Capital, Civil Society, and development. In Third Word Quarterly.

Patrik, P. (1988). Hukum Perdata II. Semarang: Undip.

Pretty, J., \& Ward, H. (2001). Sosial Capital and The Environment. World Development, 29(2).

Setiawan, R. (1979). Pokok-pokok Hukum Perikatan. Bandung: Bina Cipta. Subekti, R. (1991). Hukum Perjanjian. Jakarta: Intermasa.

Sulitnih, A. (2013). Suksesnya Bisnis Tergantung Pengetahuan Dan Penguasaan Anda.

Retrieved from https://asmatrch.wordpress.com/2013/11/10/suksesnya-bisnis- tergantungpengetahuan-dan-penguasaan-anda/

Surajiyo. (2007). Filsafat Ilmu dan Perkembangannya di Indonesia. Suatu Pengantar. Jakarta: Bumi Aksara.

Suriasumantri, J. S. (2005). Filsafat Ilmu Sebuah Pengantar Populer. Jakarta: Pustaka Sinar.

Yusriadi. (2018a). Bureaucratic Reform to the improvement of public services Challenges for Indonesia. Publikauma: Jurnal Administrasi Publik Universitas Medan Area, 6. Retrieved from http://ojs.uma.ac.id/index.php/publikauma/article/view/1494

Yusriadi. (2018b). Reformasi Birokrasi Indonesia: Peluang dan Hambatan. Jurnal Administrasi Publik (Public Administration Journal), 8 (2), 178-185. Retrieved from https://ojs.uma.ac.id/index.php/adminpublik/article/view/1824

Yusriadi. (2018c). Tantangan Reformasi Birokrasi Berbasis E-Procurement di Indonesia. Publikauma: Jurnal Administrasi Publik Universitas Medan Area, 6(2). Retrieved from https://ojs.uma.ac.id/index.php/publikauma/article/view/1635

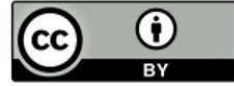

